\title{
Critical Thinking: How is it Developed with the Experiential Learning Model in Junior High School Students?
}

\author{
Anik Yuliani ${ }^{*}$, Yaya Sukjaya Kusumah ${ }^{1}$, Jarnawi Afghani Dahlan' \\ ${ }^{1}$ Universitas Pendidikan Indonesia \\ $凶$ anik_yuliani0407088601@ikipsiliwangi.ac.id*
}

\section{Article Information}

Submitted May 10, 2021

Revised May 12, 2021

Accepted May 13, 2021

\section{Keywords}

Experiential Learning;

Mathematical Critical Thinking Ability.

\begin{abstract}
This research aims to determine whether the achievement and improvement of mathematical critical thinking abilities of junior high school students who get the experiential learning model is better than those who get conventional learning and to find out which indicators of critical thinking abilities that junior high school students find difficult. This research is a quantitative research with a quasi-experimental research type. The design in this research was the randomized pretestposttest control group design. The instrument used in this research is a set of tests to describe the mathematical critical thinking ability with a system of two-variable linear equations. The analysis used in this research using the $t$ test, with a one-party hypothesis. Post-test data is used to see the achievement of mathematical critical thinking abilities and $\mathrm{N}$-gain data to see the improvement. The conclusion in this research is the achievement and improvement of mathematical critical thinking abilities of students who receive experiential learning is better than the mathematical critical thinking abilities of students who receive conventional learning. There is aspect that students find difficult, namely the advanced clarification aspect.
\end{abstract}

\section{INTRODUCTION}

Experiential learning is a learning that emphasizes student experience as a central role in the learning process, so that applying experiential learning will allow students to be actively involved in the learning process. This is in line with the opinion of (Chesimet et al., 2016) who stated that with experiential learning, students have the ability to choose and actively participate in constructing knowledge based on the experiences they get during the learning process. In addition, experience will also assist students in applying the concepts obtained to be applied to real-world situations or to new problems. Learning is obtained through the transformation of experiences that can be applied in various situations and in various disciplines (Manolas \& Kehagias, 2005; Kolb \& Kolb, 2017). (Tong et al., 2020) also emphasized that experiential learning is an important bridge between teaching in the classroom and applying it in practice.

In the experiential learning process, learning is based on the experience and reflect on what they have been learned, so it involves a body, thoughts, feelings and actions (Kolb \& Kolb, 2017). Thus, in experiential learning the learning process should be carried out by combining theoretical mastery and practical experience. (Kolb \& Kolb, 2009) explained that the best learning process is not only seen from the results, but also seen from the process. Thus, learning must be understood as a continuous reconstruction of experience, which is created by a person through the actual events they experience. The purpose of the experiential learning models is to affect students in three ways: changing the cognitive structure of 
students, change students' attitudes, and expand the skills of existing students (Priatmoko \& Dzakiyyah, 2020).

There are four stages in the experiential learning model which are believed to be able to make learning in the experiential learning model very effective. The four stages according to (Kolb, 1984) are: 1) Concrete experience; 2) Reflective observation; 3) Abstract conceptualization; 4) Active experimentation. (Kolb, 1984) explained that at the concrete experience stage, the success of learning really depends on the individual in terms of openmindedness and ability to adapt to a problem; the reflective observation stage, the stage where students consider from various perspectives the concrete experiences they have had; abstract conceptualization stage, the stage where students filter their observations and reflections to become a theory or concept; the active experimentation stage, the stage of using the theory that students have developed and then acting on the predictions they have considered. Piliouras, P \& Kokotas, P (Manolas \& Kehagias, 2005) argued that with the four stages in the experiential learning model, there were many positive things that could be obtained, one of which was encouraging critical thinking abilities.

The critical thinking ability is one of the thinking skills needed in the 21 st century where information is dynamic, therefore it is very important for students to master it. (Depdiknas, 2013) also emphasized that one of the graduation standards for junior high school and senior high school students is the development of critical thinking abilities. (Jacob, 2012; Aizikovitsh-Udi \& Cheng, 2015; Yumiati \& Kusumah, 2019; Kadarsono et al., 2019) stated that students with critical thinking abilities will be able to process information, analyze, evaluate, and be able to reason with logic. This is because critical thinking abilities will encourage students to think independently and be able to solve problems at school and in everyday contexts so that learning mathematics becomes better and more meaningful.

(Ennis, 2015) explained that critical thinking is reflective thinking that focuses on decision-making patterns about what to believe and what to do. Another idea put forward by (Hashemi, 2011) critical thinking is a skill needed to foster students' thinking skills. Meanwhile (Facione, 2011) stated that the most basic concept of critical thinking is the ability to interpret, analyze, evaluate, explain and self-regulate. Myers (Fuad et al., 2017) argued that critical thinking is a skill for examining assumptions, distinguishing hidden values, evaluating evidence and assessing conclusions. The indicators of mathematical critical thinking abilities used in this research are indicators according to (Ennis, 2015) namely: providing simple explanations (Elementary Clarification); building basic skills (Basic Support); make conclusions (Inference); make further explanations (Advanced Clarification; set strategies and tactics (Strategies and Tactics).

There are several previous researches related to experiential learning models and also mathematical critical thinking abilities. (Newsome et al., 2005) in their research stated that there was a significant interaction between learning methods and school categories on cognitive achievement and student retention.. (Hamilton \& Klebba, 2011) conducted research on business students in their research which resulted in a course design to increase the use of experiential learning techniques to foster critical thinking abilities. Then, (Astuti, 2016) conducted a research on PGSD students to conclude that there was a significant increase in students' critical thinking abilities using experiential learning models.. (Munawaroh \& Sudiyanto, 2018) conducted research on elementary students to determine the learning process of experiential learning in the classroom to improve mathematical critical thinking 
abilities. From their research, it was explained that it turns out that learning that puts more emphasis on experience can help students solve problems in mathematics learning that require good critical thinking abilities. Meanwhile, (Abdullah et al., 2020) in their research also concluded that the experiential learning model had a positive effect on students' critical thinking abilities. Likewise, (Wulandari et al., 2020) in their research found that the factors that encourage students' critical thinking abilities are the presentation of material related to the real world.

From several researches that have been mentioned above, most of the research is carried out in universities and also in elementary schools. In addition, there are those who conduct research in junior high schools, most of the research is on physics subjects. Researchers pay attention that there are no researches applying the experiential learning model to junior high school students to improve junior high school students' critical thinking abilities, especially in subjects of two-variable linear equation systems. Therefore, researchers are very interested in how to develop mathematical critical thinking abilities in the material of two-variable linear equation systems in 8th grade students of junior high school by applying the experiential learning model. This research is also a preliminary research conducted by researchers for dissertation research. As for the specific purpose of this research is to determine whether the achievement and improvement of mathematical critical thinking abilities of junior high school students who receive the experiential learning model is better than those who receive conventional learning. In addition, researchers also want to see which indicators of mathematical critical thinking abilities are found difficult by students.

\section{METHODS}

This research is a quantitative research with a quasi-experimental research type. This research was conducted at one of the state junior high schools at Cimahi Town. The population in this research were all students of $8^{\text {th }}$ grade of state junior high school, the sample was two classes, namely class $8 \mathrm{~B}$ and class $8 \mathrm{E}$. Class $8 \mathrm{~B}$ was used as the experimental class and class $8 \mathrm{E}$ was used as the control class. This research involved 708 th grade students, with the material used in this research, namely two-variable linear equations consisting of five items. The research design used was The Randomized Pre-test Post-test Control Group Design. The research design is as follows:
Experiment Class
$\mathrm{O} \quad \mathrm{X} 1 \mathrm{O}$
Control Class
$\mathrm{O} \quad \mathrm{X} 2 \quad \mathrm{O}$

Where :

$\mathrm{O}$ : Observation of the pretest / posttest

$\mathrm{X} 1 \quad$ : Treated using experiential learning model

X2 : Treated using conventional learning

Posttest data is used to see the extent to which the achievement of mathematical critical thinking skills has been applied to the experiential learning model. Meanwhile, to see the extent to which the improvement of mathematical critical thinking abilities after the application of the experiential learning model is taken from the N-Gain data. To see which is better between the critical thinking abilities in a class that gets experiential learning model or in a class that gets conventional learning, a one-party hypothesis test is carried out. The analysis used in this research was using the two-mean difference test, provided that if the two 
samples were normally distributed then it was followed by a homogeneity test then to the $t$ test. If the sample is normally distributed but not homogeneous, then proceed with the $\mathrm{t}^{\prime}$ test. Then if one of the samples is not normally distributed, then the next analysis is to the nonparametric test, namely the Mann Whitney test. The research procedure used in this research can be seen in the diagram below:

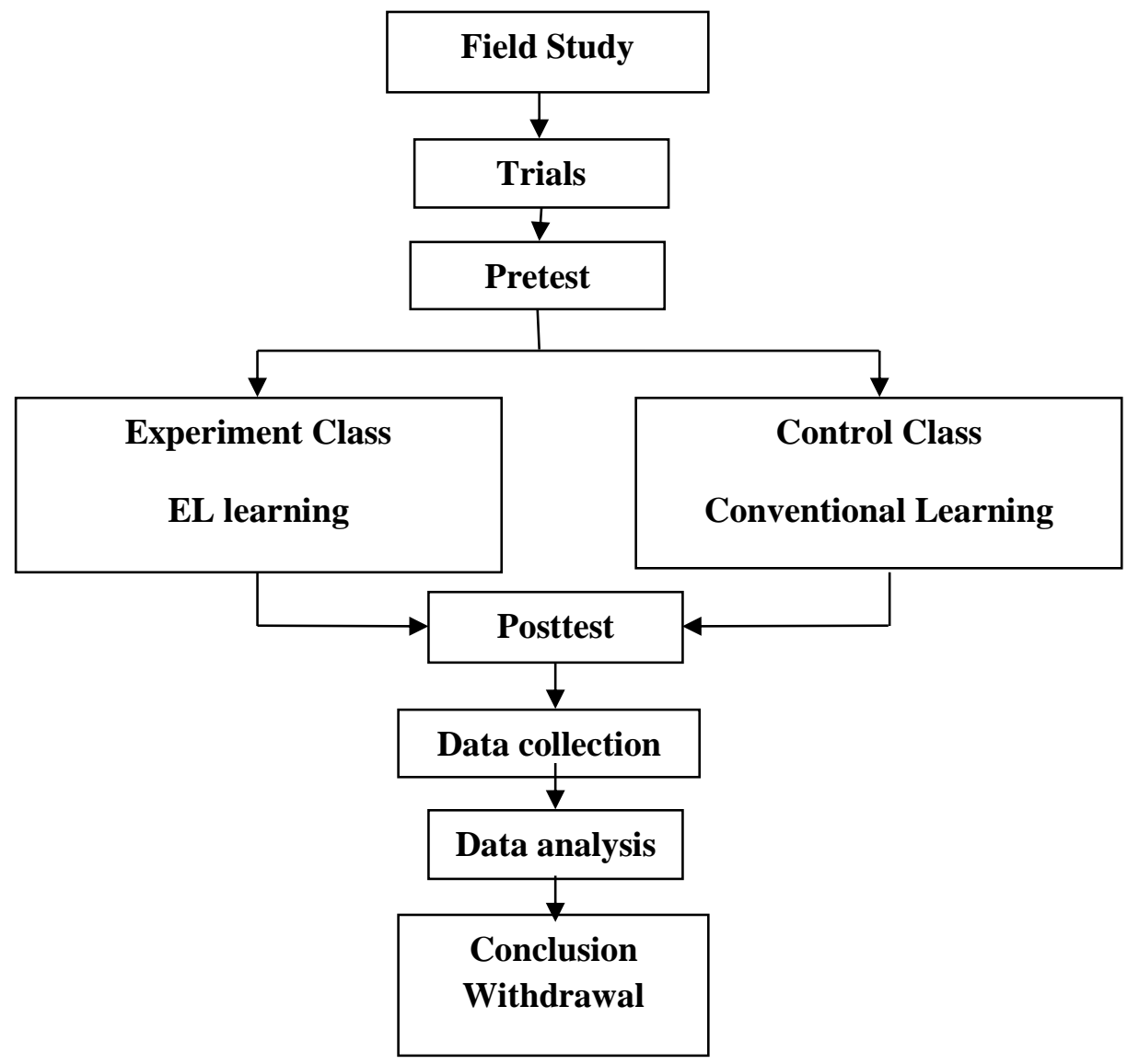

Figure 1. Experimental Procedure Flowchart

Before being used for research, the instrument was tested first. The following are the results of the analysis test of the mathematical critical thinking ability instrument used in this research.

Table 1. Instrument Description

\begin{tabular}{|c|c|c|c|c|c|c|}
\hline $\begin{array}{l}\text { Test and } \\
\text { Scale }\end{array}$ & $\begin{array}{l}\text { n } \\
\text { Subject }\end{array}$ & $\begin{array}{l}\text { n Item Test } \\
\text { \& Scale }\end{array}$ & $\begin{array}{l}\text { Discriminat } \\
\text { power }\end{array}$ & $\begin{array}{l}\text { Difficulty } \\
\text { index }\end{array}$ & $\begin{array}{l}\text { Item Validity } \\
\left(r_{\text {table }}=\mathbf{0 . 3 2}\right)\end{array}$ & $\begin{array}{l}\text { Relia- } \\
\text { bility }\end{array}$ \\
\hline KBKM & 36 & 5 & $0.35-0.41$ & $0.62-0.68$ & $0.78-0.85$ & 0.86 \\
\hline
\end{tabular}

\section{RESULTS AND DISCUSSION}

The following shows the results of descriptive statistical analysis of the critical thinking abilities of students who have learned based on experience with students who have received conventional learning. 
Table 2. Descriptive statistics

\begin{tabular}{|c|c|c|c|c|c|c|c|c|c|}
\hline \multirow{2}{*}{ Variables } & \multicolumn{2}{|c|}{ Descriptive EL $\langle\boldsymbol{g}\rangle$} & & & & \multicolumn{4}{|l|}{ PK } \\
\hline & Statistics & Pretest & Postte & & $\mathbf{n}$ & Pretest & Posttest $\langle g\rangle$ & & $\mathbf{n}$ \\
\hline \multirow{3}{*}{ KBKM } & $\bar{x}$ & 5.8 & 17.2 & 0.82 & \multirow{3}{*}{35} & 6.2 & 12.4 & 0.55 & \multirow{3}{*}{35} \\
\hline & $(\%)$ & 32.22 & 95.56 & 0.02 & & 34.44 & 68.89 & 0.53 & \\
\hline & $\mathrm{s}$ & 2.31 & 2.42 & 0.16 & & 2.57 & 3.82 & 0.13 & \\
\hline
\end{tabular}

Note: KBKM: Mathematical Critical Thinking Ability; El: Experiential Learning; PK: Conventional Learning; Ideal Score: 18

From Table 2 it can be seen that the average pretest results in the class that received experiential learning and in the class that received conventional learning were not different, and the value of critical thinking abilities was at a very low level. These are very reasonable, because students have not studied material related to mathematical critical thinking abilities. However, after learning there was a difference in the average mathematical critical thinking abilities of the two classes. Classes that receive experiential learning have a higher average achievement and improvement when compared to classes that receive conventional learning. The achievement and improvement of mathematical critical thinking abilities in students who receive experiential learning is in the high category, while the achievement and improvement of mathematical critical thinking abilities in students who receive conventional learning is in the medium category.

Furthermore, inferential statistical tests are carried out to strengthen the discoveries of the descriptive statistical analysis. Based on the analysis results of the normality test, it is concluded that the post-test and n-gain data on the mathematical critical thinking ability have a normal distribution. Then the analysis was continued to the homogeneity test, because the post-test and n-gain data also had homogeneous variances, so to see the difference between the two average mathematical critical thinking abilities in the two classes, the t test was used. Following are the results of the hypothesis test to see the achievement and improvement of critical thinking abilities in both classes.

Table 3. Hypothesis Test of Mathematical Critical Thinking Ability

\begin{tabular}{llcccll}
\hline KBKM & $\begin{array}{l}\text { Teaching } \\
\text { approach }\end{array}$ & $\overline{\boldsymbol{x}}$ & SD & $\mathbf{n}$ & $\begin{array}{l}\text { (Sig. } \\
\text { tailed) }\end{array}$ & 1- \\
\hline \multirow{2}{*}{ Posttest } & EL & 17.2 & 2.42 & 35 & $0.00<0.05$ & KBKM EL > KBKM PK \\
& PK & 12.4 & 3.82 & 35 & & N-Gain KBKM EL > N- \\
\multirow{2}{*}{ N-Gain } & EL & 0.82 & 0.16 & 35 & $0.00<0.05$ & Gain KBKM PK \\
\hline
\end{tabular}

Note: KBKM: Mathematical Critical Thinking Ability; EL: Experiential Learning; PK: Conventional Learning; Ideal Score: 18

The hypothesis for the achievement of mathematical critical thinking abilities is as follows: $\mathrm{H}_{0}: \mu_{1} \leq \mu_{2} \quad$ (The achievement of mathematical critical thinking abilities of students who receive experiential learning is not better than students who receive conventional learning) 
$\mathrm{H}_{1}: \mu_{1}>\mu_{2} \quad$ (The Achievement of mathematical critical thinking abilities of students who receive experiential learning is better than students who receive conventional learning).

In Table 3, it can be seen that the significance result of the achievement of mathematical critical thinking abilities is 0.00 , which means less than 0.05 , so it can be concluded that the achievement of mathematical critical thinking abilities of students who get experiential learning is better than the mathematical critical thinking abilities of students who get conventional learning.

The hypothesis for the improvement of mathematical critical thinking abilities is as follows:

$\mathrm{H}_{0}: \mu_{1} \leq \mu_{2}$ : (The improvement of mathematical critical thinking abilities of students who receive experiential learning is not better than students who receive conventional learning)

$\mathrm{H}_{1}: \mu_{1}>\mu_{2}:$ (Th improvement of mathematical critical thinking abilities of students who receive experiential learning is better than students who receive conventional learning)

In Table 3, it can also be seen that the significance value of the improvement of mathematical critical thinking abilities is 0.00 , which means it is smaller than 0.05 . It can be concluded that the improvement of mathematical critical thinking abilities of students who receive experiential learning is better than the improvement of mathematical critical thinking abilities of students who receive conventional learning. Based on these conclusions, it can be seen that the role of experiential learning is greater than the role of conventional learning in improving students' mathematical critical thinking abilities.

As for the cause of the achievement and improvement in mathematical critical thinking abilities of students who obtain experiential learning models better than students who receive conventional learning, this is because during learning in the experiential learning class students are given student worksheets containing the four elements in the experiential learning model learning. In this case, at the concrete experience stage, students must be involved in constructing experiences actively so that they can see a problem from various angles. Then proceed to the reflective observation stage, at this stage students make meticulous and careful observations to further break down the experience into some parts to use at a later stage. At the abstract conceptualization stage, students sort out the results of their observations and reflections to understand a theory. At this stage students are required to use logic and ideas in understanding a problem. Then in the final stage, namely the active experimentation stage, students test a theory to be able to solve problems related to everyday life. The series of the four stages are very helpful for students in developing mathematical critical thinking abilities, this is in line with the opinion of (Manolas \& Kehagias, 2005).

In the field, it also showed that students who obtained the experiential learning model at the initial meeting were still confused and were still passive in discussing, while at the second meeting to the sixth meeting the students seemed happy to make observations according to the problems presented on the student activity sheet. (Hamilton \& Klebba, 2011) in their research designed a course to improve the use of experiential learning techniques to foster critical thinking abilities. From the results of their research, it provides feedback for research that in designing student worksheets it should be interesting enough so that it can improve 
mathematical critical thinking abilities of students. In addition, in heterogeneous groups, students were seen actively conducting discussions to construct experiences in understanding the problems given in the student activity sheet. With this discussion, students with low abilities became motivated to be active in conducting discussions. These discoveries are also similar to the findings from previous researches (Jumaisyaroh et al., 2014; Kurniati et al., 2015; Astuti, 2016; Syaodih et al., 2019) that various innovative learning approaches take a bigger role than conventional learning in improving mathematical critical thinking abilities. Furthermore, to see the student abilities in problem solving related to mathematical critical thinking abilities are presented in Table 4 below.

Table 4. The Achievement Percentage of Mathematical Critical Thinking Abilities per Aspect

\begin{tabular}{lll}
\hline Aspect KBKM & EL & PK \\
\hline Elementary Clarification & $88,7 \%$ & $80 \%$ \\
Basic Support & $83,8 \%$ & $77,5 \%$ \\
Advanced Clarification & $72 \%$ & $65,4 \%$ \\
Inference & $79,7 \%$ & $72,8 \%$ \\
Strategies and Tactics & $81,8 \%$ & $70 \%$ \\
\hline
\end{tabular}

Based on the results of the achievement percentage of mathematical critical thinking abilities seen from every aspect, it can be seen that the elementary clarification aspect has the highest percentage value of achievement both in the class that received experiential learning and in the class that received conventional learning. While the least aspect can be resolved by students was the advanced clarification aspect, with the achievement percentage of $72 \%$ in the class that received experiential learning and $65.4 \%$ in the class that received conventional learning. Most of the students in both classes still had difficulty working on questions related to making further explanations. The factors that cause students experience difficulties in the aspect of making further explanations, this is because most students have not been able to see the relation between concepts in mathematics. Students focused only on problems related to the two-variable system of linear equations, while when the questions related to SPLDV were related to the concept of squares and rectangles material, students were confused to see their relations. The low aspect of making further explanations (Advanced Clarification) indicates that students still have difficulties in matters that require mathematical reasoning. These discoveries are in line with the results of (Lestari, 2014) which revealed that the low ability to build basic skills (basic support), conclude (inference), and make further explanations (advanced clarification) indicates that students still have difficulty in problem solving that require mathematical reasoning.

\section{CONCLUSIONS}

Based on the analysis results that has been carried out, the following conclusions are obtained: 1) The achievement of mathematical critical thinking abilities of students who receive experiential learning is better than the achievement of mathematical critical thinking abilities of students who receive conventional learning; 2) The improvement of students 'mathematical critical thinking abilities who received experiential learning is better than the improvement of students' mathematical critical thinking abilities who received conventional learning; 3) The achievement percentage of critical thinking abilities in the advanced clarification aspect is 
$72 \%$, so it can be concluded that the difficulties experienced by students in completing mathematical critical thinking abilities are in the advanced clarification aspect, both in classes that receive experiential learning and in classes that receive conventional learning.

The suggestions that can be given from the results of this research are an improvement in mathematical critical thinking abilities. Learning will be better if experiential learning can be applied in schools. One indicator of critical thinking abilities that is classified as low is the advanced clarification aspect. Therefore, we need a maximal effort to improve this aspect. The next researcher is expected to maximize all indicators of critical thinking abilities, so that students can provide better learning outcomes.

\section{AUTHOR CONTRIBUTIONS STATEMENT}

AY worked as the main drafter in this research. data collection and instrument design assisted by YSK and JAD.

\section{REFERENCES}

Abdullah, A. A., Shanti, W. N., \& Sholihah, D. A. (2020). Critical thinking ability through experiential learning in the calculus class. Journal of Physics: Conference Series, 1613(1).

Aizikovitsh-Udi, E., \& Cheng, D. (2015). Developing critical thinking skills from dispositions to abilities: mathematics education from early childhood to high school. Creative Education, 06(04), 455-462.

Astuti, Y. K. (2016). Pembelajaran berbasis pengalaman (experiental learning) untuk meningkatkan keterampilan berfikir kritis dan aktivitas mahasiswa. Jurnal Universitas Wiralodra, 7(3), 148-152.

Chesimet, M. C., Githua, B. N., \& Ng'eno, J. K. (2016). Effects of experiential learning approach on students' mathematical creativity among secondary school students of kericho east sub-county, Kenya. Journal of Education and Practice, 7(23), 51-57.

Depdiknas. (2013). Kurikulum 2013. In Depdiknas. Jakarta.

Ennis, R. H. (2015). Critical thinking: A streamlined conception. In The Palgrave handbook of critical thinking in higher education (pp. 31-47). Palgrave Macmillan, New York.

Facione, P. A. (2011). Critical thinking: What it is and why it counts. Insight assessment, 2007(1), 1-23.

Fuad, N. M., Zubaidah, S., Mahanal, S., \& Suarsini, E. (2017). Improving junior high schools' critical thinking skills based on test three different models of learning. International Journal of Instruction, 10(1), 101-116.

Hamilton, J. G., \& Klebba, J. M. (2011). Experiential learning: A course design process for critical thinking. American Journal of Business Education (AJBE), 4(12), 1-12.

Hashemi S A. (2011). The use of critical thinking in social science textbooks of high school: A field study of fars province in Iran. International Journal of Instruction, 4(1), 63-78. 
Jacob, S. M. (2012). Mathematical achievement and critical thinking skills in asynchronous discussion forums. Procedia - Social and Behavioral Sciences, 31, 800-804.

Jumaisyaroh, T., Napitupulu, E. E., \& Hasratuddin, H. (2014). Peningkatan kemampuan berpikir kritis matematis dan kemandirian belajar siswa SMP melalui pembelajaran berbasis masalah. Kreano, Jurnal Matematika Kreatif-Inovatif, 5(2), 157.

Kadarsono.M., Suyitno. H., \& Waluyo.B. (2019). Mathematical critical thinking ability of students in CTL learning based on cognitive style. Unnes Journal of Mathematics Education Research, 8(1), 89-95.

Kolb, A. Y., \& Kolb, D. A. (2009). Experiential learning theory: A dynamic, holistic approach to management learning, education and development. In The SAGE Handbook of Management Learning, Education and Development.

Kolb, A. Y., \& Kolb, D. A. (2017). Experiential learning theory as a guide for experiential educators in higher education. ELTHE: A Journal for Engaged Educators, 1(1), 7-45.

Kolb, D. (1984). Experiential learning: Experience as the source of learning and development. In Englewood Cliffs, NJ: Prentice Hall. New Jersey.

Kurniati, K., Kusumah, Y. S., Sabandar, J., \& Herman, T. (2015). Mathematical critical thinking ability through contextual teaching and learning approach. Journal on Mathematics Education, 6(1), 53-62.

Lestari, K. E. (2014). Impelementasi brain-based learning untuk meningkatkan kemampuan koneksi dan kemampuan berpikir kritis serta motivasi belajar siswa SMP. Jurnal Pendidikan UNSIKA, 2(1), 36-46.

Manolas, E., \& Kehagias, T. (2005). Kolb's experiential learning model: Enlivening physics courses in primary education. Proceedings of the 2nd International Conference, Handson Science: Science in a Changing Education, 286-289.

Munawaroh, H., \& Sudiyanto, R. An analysis experiential learning on the mathematical critical thinking ability in primary school.

Newsome, L.A., Wardlow, G.W., \& J. D. M. (2005). Effects of lecture versus experiential teaching method on cognitive achievement, retention and attitudes among high school agriscience students. National AAAE Research Conference, 146-156.

Priatmoko, S., \& Dzakiyyah, N. . (2020). Relevansi kampus merdeka terhadap kompetensi guru era 4.0. At-Thullad Jurnal Pendidikan Guru Madrasah Ibtidaiyah, 4, 1-15.

Syaodih, E., Suhandi, A., Ningsih, A. R., Fratiwi, N. J., \& Samsudin, A. (2019). Improving primary students ${ }^{6}$ critical thinking skills through experiential learning assisted tools of science for kids (EL-TSK) on magnetic force concept. International Journal of Scientific and Technology Research, 8(10), 3734-3738.

Tong, D. H., Loc, N. P., Uyen, B. P., \& Cuong, P. H. (2020). Applying experiential learning to teaching the equation of a circle: A case study. European Journal of Educational Research, 9(1), 239-255. 
Wulandari, P., Mujib, M., \& Putra, F. G. (2020). Meta-analysis: The effect of problem approach and inquiry approach toward students' mathematical critical thinking skill over the past 4 years. Al-Jabar: Jurnal Pendidikan Matematika, 11(1), 101-106.

Yumiati, \& Kusumah.Y.S. (2019). Interaction between students' learning and early mathematical skills to increase mathematical critical thinking. Al-Jabar: Jurnal Pendidikan Matematika.,10(1), 125-134. 